\title{
HUKUM PEMBATALAN HIBAH DARI ORANG TUA KEPADA ANAKNYA
}

\author{
Elfran Bima Muttaqin ${ }^{1}$, Andi Aspiani Eka²
}

\begin{abstract}
Abstrak
Hibah merupakan pemberian cuma-cuma suatu benda untuk keperluan penerima hibah dan tidak tidak dapat ditarik kembali. Pengaturan mengenai hibah terdapat baik dalam hukum nasional yang termuat dala KUH Perdata dan Kompilasi Hukum Islam. Meskipun bersifat pemberian cuma-cuma, dalam pelaksanaannya, beberapa kasus terjadi penarikan atau pembatalan hibah dari orang tua kepada anaknya. Permasalahan yang diteliti dalam penelitian ini adalah penyebab batalnya hibah dari orang tua kepada anaknya dan dasar pertimbangan hakim dalam menentukan hukum untuk menentukan putusan atas pembatalan hibah dari orang tua kepada anaknya. Berdasarkan hasil penelitian yang diperoleh bahwa terjadinya pembatalan suatu hibah ialah apabila barang yang dihibahkan melebihi batas maximum pemberian hibah yaitu sepertiga dari harta kekayaan pemberi hibah dan ada ketidaksesuaian dengan maksud ataupun tujuan pemberian hibah, dan yang menjadi pertimbangan hakim dalam memutus perkara pembatalan hibah yaitu pemberi hibah menghibahkan hartanya kepada penerima hibah dengan syarat bahwa penerima hibah akan merawat pemberi hibah hingga meninggal dunia tetapi penerima hibah tidak memenuhi syarat tersebut. Dasar hukum pertimbangan tersebut adalah Pasal 1688 KUHPerdata Ayat (1) serta Kompilasi Hukum Islam Pasal 212.
\end{abstract}

Kata Kunci: Pembatalan, Hibah

\section{PENDAHULUAN}

\subsection{Latar Belakang}

Hibah merupakan suatu perjanjian dengan mana si penghibah, di waktu hidupnya, dengan cumacuma dan dengan tidak dapat ditarik kembali, menyerahkan suatu benda guna keperluan si penerima hibah yang menerima penyerahan itu (Pasal 1666 KUHPerdata). Hibah dalam KUHPerdata digolongkan sebagai perjanjian dengan cuma-cuma yang ditujukan hanya adanya prestasi dari satu pihak saja, sedangkan pihak yang lainnya tidak memberikan kontra prestasi, hibah dalam KUHPerdata ini merupakan bagian dari hukum per-janjian dan digolongkan perjanjian untuk memberikan atau menyerahkan sesuatu diwaktu hidupnya.

Namun demikian apabila terdapat persyaratan yang digantungkan oleh si penghibah maka si penerima hibah wajib untuk memikulnya sebab bilamana tidak dilaksanakan maka hibah yang telah diberikan dapat ditarik kembali. Kadangkala karena sesuatu hal seseorang membatalkan apa yang telah ia berikan kepada orang lain yang dikarenakan tidak dipenuhinya prestasi. Begitu juga dengan hibah ini, meskipun hibah yang sudah diberikan kepada orang lain termasuk diberikan kepada anaknya sendiri ini telah dibuatkan akta yang sah dihadapan Notaris tapi kadang kala ada yang mencabut atau menariknya kembali. Yang dimaksud dengan mencabut dan menariknya kembali dalam hal ini tidak lain adalah membatalkan hibah.

Di dalam kompilasi Hukum islam hibah tidak boleh ditarik kembali, meskipun hibah itu terjadi antara dua orang yang bersaudara atau suami istri. Adapun hibah yang boleh ditarik kembali adalah hibah yang dilakukan oleh orang tua kepada anaknya (Pasal 212 Kompilasi Hukum Islam). Ulama Fiqh berpendapat apabila benda hibah masih dimiliki anak atau masih bergabung dengan milik orang tuanya dapat dicabut, tetapi apabila sudah bercampur dengan harta miliknya, istrinya atau dengan harta orang lain tidak dapat dicabut kembali. Undang-undang memberikan kemungkinan bagi si penghibah untuk dapat menarik kembali hibah yang telah di berikan kepada seseorang dengan alasan-alasan tertentu dan dalam keadaan tertentu.

\footnotetext{
${ }^{1}$ Dosen Fakultas Hukum Universitas Kristen Indonesia Paulus Makassar

${ }^{2}$ Mahasiswa Fakultas Hukum Universitas Kristen Indonesia Paulus Makassar
} 
Upaya hukum yang dapat dilakukan untuk menuntut hak adalah dengan mengajukan gugatan ke Pengadilan, dengan cara meminta kepada hakim untuk memeriksa dan memutus perkara yang di sengketakan.

Mengenai perkara hibah merupakan kompetensi absolut pengadilan agama untuk mengadili dan memutus suatu perkara sebagamana yang tertuang dalam Pasal 49 Undang-Undang nomor 3 Tahun 2006 tentang Perubahan Atas Undang-Undang nomor 7 Tahun 1989 Tentang Peradilan Agama. Mengenai proses penyelesaian pembatalan hibah melalui pengadilan tidaklah mudah dilakukan karena dalam proses persidangan itu memerlukan adanya suatu pembuktian.

Dalam praktek, majelis hakim memerlukan ketelitian dan kebijaksanaan untuk menetukan pihak mana yang perlu diberi beban pembuktian lebih dahulu dan selanjutnya. Pasal 163 HIR,283 Rbg mengatur beban pembuktian, tetapi tidak begitu jelas sehingga sulit untuk diterapkan secara tegas apakah beban pembuktian ada pada penggugat atau tergugat.

Dalam sengketa yang diajukan dimuka persidangan tersebut para pihak yang bersengketa memajukan dalil-dalil yang saling bertentangan. Hakim harus memeriksa dan menetapkan dalil-dalil manakah yang benar dan dalil manakah yang tidak benar. Dalam melaksanakan pemeriksaan ini pula hakim harus mengindahkan aturan-aturan tentang pembuktian yang merupakan hukum pembuktian.

Pengadilan sebagai peradilan pelaksana hukum dalam hal adanya tuntutan hak harus berdiri sendiri dan bebas dari pengaruh apa atau siapapun dengan cara memberikan putusan yang bersifat mengikat dan bertujuan mencegah terjadinya main hakim sendiri sehingga hakim harus bebas dari pengaruh apa dan siapaun untuk memberikan putusan yang seadil-adilnya.

\subsection{Permasalahan}

1. Apa yang menjadi penyebab batalnya hibah dari orang tua kepada anaknya ?

2. Apa saja yang menjadi dasar pertimbangan hakim dalam menentukan hukum untuk menentukan putusan atas pembatalan hibah dari orang tua kepada anaknya ?

\subsection{Tujuan Penelitian}

1. Untuk mengetahui penyebab batalnya hibah dari orang tua kepada anaknya.

2. Untuk mengetahui dasar pertimbangan hakim dalam menentukan hukum untuk menentukan putusan atas pembatalan hibah dari orang tua kepada anaknya.

\section{LANDASAN TEORI}

\subsection{Pengertian Hibah Hibah Menurut Hukum Islam}

Kata hibah berasal dari bahasa Arab berarti pemberian yang dilakukan seseorang saat dia masih hidup kepada orang lain tanpa imbalan (pemberian cuma-cuma), baik berupa harta atau bukan harta. Diantaranya kata ini digunakan dalam firman Allâh Azza wa Jalla yang jika ditafsirkan : "Dan sesungguhnya aku khawatir terhadap mawaliku sepeninggalku, sedang isteriku adalah seorang yang mandul, maka anugerahilah aku dari sisi Engkau seorang putra yang akan mewarisi aku dan mewarisi sebahagian keluarga Ya'qûb; dan jadikanlah ia, ya Rabbku, seorang yang diridhai" [Maryam/19:5-6].

Sedangkan pengertian hibah menurut para Ulama ahli fikih, disampaikan syaikh Abdurrahmân as-Sa'di rahimahullah dengan ungkapan yaitu pemberian harta cuma-cuma dalam keadaan hidup dan sehat. Menurut Sayid Sabiq hibah adalah akad yang pokok persoalannya pemberian harta milik seseorang kepada orang lain diwaktu dia hidup, tanpa adanya imbalan. Sulaiman Rasyid memberikan definisi hibah ialah memberikan zat dengan tidak ada tukarnya dan tidak ada karenannya. Sementara itu, H.M. Arsyad Thalib Lubis menyatakan bahwa hibah ialah memberikan suatu untuk jadi milik orang lain dengan maksud berbuat baik yang dilakukan dalam masa hidup orang yang memberi.

Dengan demikian pengertian hibah adalah pemberian yang dilakukan oleh seseorang kepada pihak lain yang dilakukan ketika masih hidup dan dalam keadaan sehat. Serah terima harta yang diberikan itu dilakukan pada waktu penghibah masih hidup.

Pemberian harta oleh manusia tanpa imbalan (tabarru') kepada orang lain terbagi menjadi dua (yaitu) yang berhubungan dengan kematian yaitu wasiat dan yang dilaksanakan dalam masa hidupnya. Pengertian kedua ini terbagi menjadi dua jenis, yaitu murni pemberian (at-tamlîk al-mahdh) seperti hibah dan sedekah, dan wakaf.

Pemberian murni dibagi menjadi tiga jenis yaitu hibah, hadiah dan sedekah tatawwu' (sedekah yang hukumnya tidak wajib). Cara membedakannya adalah pemberian tanpa bayaran adalah hibah, 
apabila diiringi dengan memin-dahkan barang yang diberikan dari tempat ke tempat orang yang diberi sebagai bentuk penghormatan dan pemuliaan maka itu dinamakan hadiah. Apabila diiringi dengan pemberian kepada orang yang membutuhkan (miskin) dalam rangka mendekatkan diri kepada Allâh Azza wa Jalla dan mencari pahala akhirat maka dinamakan sedekah. Perbedaan hadiah dari hibah adalah dengan dipindahkan dan dibawa dari satu tempat ketempat lainnya.

Berkaitan dengan hibah ini, dapat disimpulkan bahwa hibah merupakan perjanjian sepihak yang dilakukan oleh penghibah ketika hidupnya untuk memberikan suatu barang dengan cuma-cuma kepada penerima hibah dan Hibah harus dilakukan antara dua orang yang masih hidup.

\subsection{Dasar Hukum Hibah}

Hibah ini disyariatkan Allâh Azza wa Jalla sebagaimana dijelaskan dalam al-Qur`an dan asSunnah serta sudah menjadi kesepakatan para Ulama. Adapun dalil dari Al-Qur`an adalah firman Allâh Azza wa Jalla yang tafsirnya : Berikanlah mas kawin (mahar) kepada wanita (yang kamu nikahi) sebagai pemberian dengan penuh kerela-an. Kemudian jika mereka menyerahkan kepada kamu sebagian dari maskawin itu dengan senang hati, maka makanlah (ambillah) pemberian itu (sebagai makanan) yang sedap lagi baik akibatnya (An-Nisâ'/4:4).

Dalam ayat ini Allâh Azza wa Jalla menghalalkan memakan sesuatu yang berasal dari hibah. Ini menun-jukkan bahwa hibah itu boleh. Sedangkan dalam sabda Rasûlullâh Shallallahu 'alaihi wa sallam banyak sekali, diantaranya sabda Rasûlullâh Shallallahu'alaihi wa sallam : Saling memberilah kalian, niscaya kalian saling mencintai (HR.Al-Bukhâri dalam al-Adâbul Mufrad no. 594. Hadits ini dinilai sahih oleh al-Albâni dalam kitab al-Irwa', no. 1601). Demikian juga sabda Beliau Shallallahu 'alaihi wa sallam : Orang yang menarik kembali hibahnya seperti anjing yang menjilat kembali muntahnya (HR. Al-Bukhâri).

Larangan menarik kembali hibah dalam hadits ini menunjukkan secara tegas bahwa hibah ini di syari'at-kan. Demikian telah ada ijma' atas pensyariatannya. (Lihat Durar al-Hukâm Syarh Majallâh alAhkâm, 1/396). Adapun hibah tertuang dalam Kompilasi Hukum Islam antara lain; Orang yang telah berumur sekurang-kurangnya 21 tahun berakal sehat tanpa adanya paksaan dapat menghibahkan sebanyak-banyaknya $1 / 3$ harta benda-nya kepada orang lain atau lembaga di hadapan dua orang saksi untuk dimiliki. Harta benda yang dihibahkan harus merupakan hak dari penghibah (Pasal 210).

Hibah dan orang tua kepada anaknya dapat diperhitungkan sebagai warisan. (Pasal 211 Kompilasi Hukum Islam) Hibah tidak dapat ditarik kembali, kecuali hibah orang tua kepada anaknya. (Pasal 212 Kompilasi Hukum Islam). Hibah yang diberikan pada saat pemberi hibah dalam keadaan sakit yang dekat dengan kematian, maka harus mendapat persetujuan dari ahli warisnya. [Pasal 213 Kompilasi Hukum Islam).

Warga negara Indonesia yang berada di negara asing dapat membuat surat hibah di hadapan Konsulat atau Kedutaan Republik Indonesiasetempat sepanjang isinya tidak bertentangan dengan ketentuan pasal-pasal ini. Pasal 214 Kompilasi Hukum Islam. Pembatalan dan Penarikan Hibah dari Ibnu Abbas dan Ibnu Umar bahwa Nabi Muhammad SAW bersabda: "Tidak halal bagi seorang lelaki untuk memberikan pemberian atau menghibahkan suatu hibah, kemudian dia mengambil kembali pemberiannya, kecuali hibah itu dari orang tua kepada anaknya. Perumpamaan bagi orang yang memberikan suatu pemberian kemudian dia rujuk didalamnya (menarik kembali pemberiannya), maka dia itu bagaikan anjing yang makan, lalu setelah anjing itu kenyang ia muntah, kemudian ia memakan muntahnya itu kembali".

Hadis diatas begitu tegas membatasi suatu pemberian agar tidak sekehendak pribadi seseorang dapat dengan semaunya mengambil kembali suatu pemberian yang sudah diberikan kepada orang lain, tentunya itu sangat melukai perasaan sipenerima, kecuali hibah itu dari orang tua kepada anaknya.

Adapun tata cara penarikan suatu hibah tidak diatur secara rinci diatur dalam Kompilasi Hukum Islam, namun demikian dapat ditemukan dalam Pasal 1688 KUHPerdata yang memungkinkan seseorang dapat mencabut kembali hibahnya apabila terjadi hal-hal sebagai berikut: Karena Si penerima hibah tidak memenuhi syarat-syarat yang telah ditentukan oleh si Penghibah.

Si penerima hibah telah bersalah melakukan sesuatu kejahatan yang bertujuan meng-hilangkan jiwa si Penghibah, atau sesuatu kejahatan dalam bentuk lain yang bertujuan mencelakakan diri si penghibah. Jika penerima hibah menolak untuk mem-berikan tunjangan nafkah terhadap diri si penghibah, apabila ia jatuh miskin. 


\section{METODE PENELITIAN}

\subsection{Lokasi Penelitian}

Penulis memilih lokasi penelitian di Kabupaten Gowa, khususnya di Pengadilan Agama Sungguminasa. Adapun alasan memilih lokasi penelitian ini karena adanya kasus pembatalan akta hibah di Pengadilan Agama Sungguminasa.

\subsection{Jenis dan Sumber Data}

Sumber data yang digunakan dalam penelitian ini terdiri atas dua kategori, yaitu data primer dan data sekunder :

1. Data primer yaitu data yang diperoleh langsung dari nasumber dilokasi penelitian.yang berkaitan dengan Pembatalan Hibah.

2. Data sekunder yaitu data yang diperoleh melalui studi kepustakaan dengan cara menelaah literature, artikel, makalah serta peraturan perundang-undangan yang ada kaitannya dengan Pembatalan Hibah.

\subsection{Teknik Pengumpulan Data}

Metode pengumpulan data dilakukan dengan dua cara yaitu :

1. Teknik Telaah Pustaka dan Dokumen

Yaitu penulis melakukan pengumpulan data dengan cara membaca sejumlah literature yang relevan tentang Pembatalan Hibah, serta bahan-bahan normatif berupa produk hukum (Putusan Pengadilan Agama).

2. Wawancara

Yaitu penulis mendatangi lokasi penelitian kemudian melakukan wawancara secara langsung guna menge-tahui apakah yang menjadi pertimbangan hakim dalam memutuskan perkara Pembatalan hibah.

\subsection{Analisis Data}

Data penelitian diolah dan dianalisis secara kualitatif deskriptif yaitu menganalisa data berdasarkan kualitas-nya lalu dideskripsikan dengan menggunakan kata-kata sehingga diperoleh bahasan atau paparan dalam bentuk kalimat yang sistematis dan dapat dimengerti, kemudian ditarik kesimpulan.

\section{HASIL DAN PEMBAHASAN}

\subsection{Faktor-Faktor Yang Menyebabkan Batalnya Hibah}

Menurut Najmin, salah seorang majelis hakim Pengadilan Agama Sungguminasa yang menjadi faktor pembatalan hibah ialah:

1. Pada dasarnya hibah tersebut terdapat syarat tertentu yang tidak dipenuhi oleh penerima hibah.

2. Penerima hibah menelantarkan harta hibah

Dalam hal terdapat syarat tertentu yang tidak dipenuhi oleh penerima hibah yaitu dimana pemberi hibah pada saat memberikan hibah memberi syarat bahwa peneri-ma hibah harus merawatnya sampai ia meninggal dunia tetapi si penerima hibah menelantarkan pemberi hibah.

Sedangkan dalam hal penerima hibah menelantarkan barang hibah, sebagai contoh apabila sebidang tanah, dengan maksud dari pemberi hibah agar tanah yang diberikan itu ditangani sehinggah dapat menghasilkan pendapatan dari hasil panennya. Namun pada pelak-sanaannya penerima hibah menelantarkan tanah pemberian tersebut sehingga tanah menjadi tandus dan tidak dapat diolah kembali maka pemberian hibah ini dapat dilakukan pembatalan atau pencabu-tan kembali.

Mengenai sebab - sebab hibah dapat dibatalkan, Najmi, dalam wawancara menjelaskan bahwa penyebab suatu hibah dapat dibatalkan adalah sebagai berikut:

1. Karena barang yang dihibahkan melebihi batas maximum pemberian hibah yaitu $1 / 3$ dari harta kekayaan pemberi hibah.

2. Karena tidak sesuai dengan maksud dan tujuan pemberian hibah.

3. Penerima hibah menjadi tidak cakap hukum.

Berdasarkan uraian di atas penyebab pertama suatu hibah dapat dibatalkan pada dasarnya sama dengan ketentuan dalam hukum islam, dimana seseorang dalam memberikan hibah banyaknya yang akan diberikan dibatasi oleh hukum yaitu maksimal 1/3 dari harta kekayaan pemberi hibah. Oleh karena itu apabila terjadi pemberi hibah memberikan hibah kepada orang lain melebihi batas tersebut maka keluarga pemberi hibah dapat mengajukan pembatalan terhadap hibah tersebut. 
Penyebab kedua suatu hibah dapat dibatalkan adalah karena tidak sesuai dengan maksud dan tujuan dari pemberi hibah. penyebab yang kedua ini haruslah mendapatkan perhatian yang khusus sebab berdasarkan dari hasil keterangan diatas menujukkan adanya perbedaan yang tajam antara hibah dalam konteks hukum Islam dengan hibah dalam Konteks hukum Perdata dimana pada dasarnya seseorang memberikan hibah kepada orang lain tidak dengan maksud dan adanya tujuan tertentu atau mengharapkan adanya timbal imbalan dari pihak lain, sementara itu dalam konteks hukum perdata dikenal adanya persyaratan-persyaratan tertentu dalam pemberian suatu hibah.

Lain halnya hibah dalam hadis dan berbagai dalil yang telah dikemukakan diatas tak satupun ada pendapat yang menerangkan atau menunjukkan bahwa menghibahkan suatu barang meski ada persyaratan tertentu yang harus digantungkan yang apabila tidak dipenuhi maka hibah akan dapat ditarik kembali. Tetapi meski demikian adapun hibah itu dapat ditarik kembali yakni apabila hibah itu adalah hibah dari orang tua kepada anaknya.

\subsection{Pertimbangan Hukum Bagi Hakim Dalam Pembatalan Hibah}

Kewenangan untuk memeriksa dan memutus kasus penarikan/pembatalan hibah dalam kasus ini adalah kewenangan Pengadilan Agama Sungguminasa, pada tanggal 17 Oktober 2015 dengan nomor perkara 765/Pdt.G/2015/PA Sgm. Perkara ini terjadi pada tahun 2015, terdaftar pada register perkara Pengadilan Agama Sungguminasa 19 Oktober 2015, dengan nomor perkara765/Pdt.G/2012/PA Sgm. tentang permohonan pembatalan hibah. Perkara ini di ajukan oleh Penggugat, dalam hal ini telah memberikan kuasa kepada Mahmud, S.H., M.H., advokat, beralamat di jalan Al Azhar Lr. 3 No. 1 Batangkaluku, Kelurahan Sungguminasa, Keca-matan Soma Opu, Kabupaten Gowa, yang selanjutnya disebut penggugat. Nasaruddin bin Yabang, agama Islam, tempat kediaman di kampong Tala-Tala, Kelurahan Bonto Kio, Kecamatan Pangkajene, Kabu-paten Pangkajene Kepulauan, sebagai Tergugat;

Berikut petikan putusannya;

1. Mengabulkan gugatan Penggugat untuk seluruhnya;

2. Menyatakan Tergugat telah melanggar kesepakatan yang telah disepakati antara Penggugat dan Tergugat;

3. Menyatakan batal demi hukum Akta Hibah Nomor 031/KSO/KBB///2014 tanggal 15 Januari 2014 berkenaan dengan tanah beserta 1 (satu) buah rumah diatasnya yang terletak di Jalan Kenanga No.

11, Kelurahan BontoBontoa, Kecamatan Somba Opu, Kabupaten Gowa. Adapun batas-batasnya:

- Utara berbatasan dengan rumah milik Mahbul Dg Lewa.

-. Timur berbatasan dengan tanah milik Nanneng.

- Selatan berbatasan dengan rumah Ake.

- Barat berbatasan dengan perpustakaan Abd. Rasyid Dg Lurang

4. Menghukum Tergugat untuk mengembalikan tanah yang telah dihibahkan tersebut kepada Penggugat dalam keadaan kosong dan tanpa ada beban suatu apapun;

5. Menghukum Tergugat untuk membayar seluruh biaya yang timbul berkenaan dengan perkara ini.

Adapun pertimbangan-pertimbangan hukum Hakim dalam memutus perkara pembatalan hibah pada perkara nomor 765/Pdt.G/2015/PA. Sgm. adalah sebagai berikut :

1. Menimbang, bahwa maksud dan tujuan gugatan Penggugat adalah sebagaimana terurai di atas;

2. Menimbang, bahwa dari posita gugatan Penggugat telah jelas menunjukkan sengketa hibah dan dengan didasarkan kepada dalil Penggugat sendiri tentang domisili Penggugat yang berada di wilayah hukum Pengadilan Agama Sungguminasa, maka dengan di dasarkan kepada ketentuan Pasal 49 ayat (1) huruf (b) Undang- Undang Nomor 7 Tahun 1989 yang telah diubah dengan UndangUndang Nomor 50 Tahun 2009 sebagai perubahan kedua, maka Pengadilan Agama Sungguminasa berwenang menerima, meme-riksa, mengadili gugatan Penggugat; Menimbang, bahwa berdasarkan Pasal $154 \mathrm{RBg}$ dan Peraturan Mahkamah Agung Nomor 1 Tahun 2008 tentang Mediasi dalam perkara perdata harus dilakukan Mediasi, dan oleh karena Tergugat dalam perkara ini tidak pernah hadir sehingga proses mediasi tidak dapat dilaksanakan, akan tetapi Majelis Hakim tetap berusaha memberikan nasehat kepada Penggugat agar menyelesaikan perkara ini secara kekeluargaan, namun tidak berhasil;

3. Menimbang, bahwa dari posita gugatan Penggugat, majelis menilai bahwa yang dijadikan alasan gugatan Penggugat adalah hibah yang diberikan oleh Penggugat kepada anaknya yaitu Tergugat agar dibatalkan dan akta hibah yang telah dibuat di hadapan Pejabat Pembuat Akta Tanah Sementara 
(PPATS) atas hibah Penggugat kepada Tergugat dinyatakan batal demi hukum, oleh karenanya secara formal gugatan Penggugat patut diterima dan dipertimbangkan;

4. Menimbang, bahwa dari posita gugatan Penggugat, majelis menilai bahwa yang menjadi penyebab Peng-gugat membatalkan hibah kepada Tergugat adalah karena Tergugat tidak melaksanakan isi perjanjian hibah yang intinya bahwa Tergugat akan menjaga dan memelihara Penggugat dan istrinya sampai meninggal dunia jika Penggugat akan memberikan tanah beserta bangunan rumah sebagaimana gugatan Penggugat, akan tetapi Tergugat justru pergi meninggalkan Penggugat ke Kabupaten Pangkep dan tidak pernah kembali lagi;

5. Menimbang, bahwa berdasarkan dalil-dalil Penggugat tersebut di atas, maka yang menjadi pokok sengketa dalam perkara ini adalah sebagai berikut:

a. Apakah penghibahan atas tanah dan sebuah rumah yang berdiri di atasnya dari Penggugat kepada Tergugat telah sesuai dengan ketentuan hukum Islam dan ketentuan hukum yang berlaku?

b. Apakah Tergugat telah melanggar isi perjanjian (wanprestasi) hibah yang diberikan oleh Penggugat? Menimbang, bahwa ternyata Tergugat tidak pernah hadir dipersidangan meskipun telah dipanggil dengan resmi dan patut, dan ketidakhadiran Tergugat tersebut tidak ternyata disebabkan oleh suatu halangan yang sah, sehingga berdasarkan ketentuan Pasal 149 ayat (1) R.Bg., sepanjang gugatan Penggugat beralasan dan berdasar hukum, maka gugatan Penggugat dapat dikabulkan dengan verstek;

6. Menimbang, bahwa meskipun gugatan Penggugat dapat dikabulkan dengan verstek, akan tetapi menurut pendapat Majelis Hakim bahwa untuk mengetahui lebih jauh kualitas materiil tentang adanya proses hibah dan alasan pembatalan hibah, maka kepada Penggugat tetap dibebani kewajiban untuk membuktikan dalil-dalil gugatannya sesuai ketentuan Pasal 283 R.Bg;

7. Menimbang, bahwa untuk menguatkan dalil gugatan-nya Penggugat telah mengajukan bukti surat bertanda P.1 dan P. 2 serta 2 orang saksi, masing-masing bernama Badaruddin dan Muh. Daniel bin Badaruddin;

8. Menimbang, bahwa berdasarkan bukti P.1 berupa fotokopi Akta Hibah Nomor 031/KSO/KBB/I/2014, tertanggal 15 Januari 2014, yang dikeluarkan oleh Pejabat Pembuat Akta Tanah Sementara (PPATS) Camat Kecamatan Somba Opu, Kabupaten Gowa, yang telah sesuai dengan aslinya serta telah bermeterai cukup, karena itu bukti P.1 tersebut telah memenuhi syarat formil suatu akta autentik, dan dalam bukti P.1 tersebut menerangkan bahwa Penggugat telah memberikan hibah kepada Tergugat berupa tanah beserta rumah di atasnya, dengan demikian bukti P.1 tersebut dinilai telah memenuhi syarat materil suatu akta autentik, dan oleh karena bukti P.1 telah memenuhi syarat formil dan materil akta autentik, maka bukti P.1 tersebut bersifat sempurna dan memiliki kekuatan pembuktian yang mengikat, sehingga harus dinyatakan terbukti bahwa tanah beserta bangunan rumah di atasnya berdasarkan Sertifikat Hak Milik (SHM) Nomor 00156 telah dihibahkan oleh Penggugat kepada Tergugat;

9. Menimbang, bahwa berdasarkan bukti P.2 berupa Fotokopi Sertifikat Hak Milik Nomor 00156, tertanggal 24 Februari 2000, yang dikeluarkan oleh Kepala Kantor Badan Pertanahan Kabupaten Gowa, yang telah sesuai dengan aslinya serta telah bermeterai cukup, karena itu bukti P.2 tersebut telah memenuhi syarat formil suatu akta autentik, dan dalam bukti P.2 tersebut menerangkan bahwa tanah beserta bangunan sebagai objek hibah adalah harta milik Penggugat dan saat ini belum terjadi pengalihan hak kepada Tergugat, dengan demikian bukti P.2 tersebut dinilai telah memenuhi syarat materil suatu akta autentik, dan oleh karena bukti P.2 telah memenuhi syarat formil dan materil akta autentik, maka bukti P.2 tersebut bersifat sempurna dan memiliki kekuatan pembuktian yang mengikat, sehingga harus dinyatakan terbukti bahwa tanah beserta bangunan di atasnya yang dijadikan objek hibah, saat ini masih berstatus hak milik Penggugat;

10. Menimbang, bahwa Penggugat mendalilkan bahwa Penggugat berjanji akan memberikan tanah dan bangunan rumah tempat tinggalnya kepada Tergugat dengan syarat Tergugat akan menjaga dan memelihara Penggugat dan istrinya sampai meninggal dunia bahkan halitu diketahui dan disetujui oleh anak-anak Penggugat yang lainnya, dan atas dalilnya tersebut Penggugat mengajukan 2 orang saksi yang dinilai telah memenuhi syarat formil sebagai bukti saksi, dimana kedua saksi memberikan keterangan yang saling bersesuaian satu sama lain dan mendukung dalil gugatan Penggugat, oleh karena itu Majelis Hakim berpendapat bahwa terbukti Penggugat telah menghibahkan tanah beserta bangunan rumah tempat tinggalnya kepada Tergugat dengan syarat Tergugat akan menjaga dan memelihara Penggugat dan istrinya sampai meninggal dunia; 
11.Menimbang, bahwa mengenai dalil gugatan Penggugat perihal Tergugat tidak melaksanakan isi perjanjian hibah untuk menjaga dan memelihara Penggugat dan istrinya sampai meninggal dunia, kedua saksi tersebut telah memberikan keterangan bersesuaian satu sama lain dan mendukung dalil Penggugat bahwa saat ini Penggugat telah lanjut usia dan sudah sakit-sakitan sedangkan Tergugat tidak menjaga dan memelihara Penggugat bahkan Tergugat telah pergi meninggalkan Penggugat sejak satu tahun lalu sampai sekarang, oleh karena itu menurut pendapat Majelis Hakim bahwa terbukti Tergugat telah melakukan perbuatan melawan hukum (wanprestasi) dengan melanggar isi perjanjian hibah antara Penggugat dengan Tergugat;

12.Menimbang, bahwa berdasarkan bukti P.1, P.2 dan 2 orang saksi yang diajukan oleh Penggugat serta telah dipertimbangkan di atas, maka telah ditemukan fakta-fakta dalam persidangan adalah sebagai berikut :

- Bahwa tanah seluas 163 M2 beserta bangunan rumah di atasnya seluas 150 M2 (Sertifikat Hak Milik Nomor 00156) yang terletak di Jl. Kenanga No. 11, Kelurahan Bonto-Bontoa, Kecamatan Somba Opu, Kabupaten Gowa, dengan batas-batas sebagai berikut :

- Sebelah Utara : rumah milik Mahbul Dg Lewa;

- Sebelah Timur : tanah milik Nanneng;

- Sebelah Selatan : rumah milik Ake;

- Sebelah Barat : perpustakaan Abd. Rasyid Dg Lurang; Telah dihibahkan oleh Penggugat kepada Tergugat dengan Akta Hibah Nomor 031/KSO/KBB/I/2014 tertanggal 15 Januari 2014;

- Bahwa peralihan hak atas tanah beserta bangunan rumah sebagaimana tersebut di atas berdasarkan hibah, hendak dibatalkan oleh Penggugat karena Tergugat tidak memenuhi isi dan/atau syarat perjanjian lisan yang dibuat oleh Penggugat dengan Tergugat, dimana Tergugat akan merawat Penggugat dan istrinya yang sudah tua dan sakit-sakitan hingga meninggal dunia;

- Bahwa Tergugat telah pergi meninggalkan Penggugat sampai sekarang ke Pangkep tidak pernah kembali lagi yang sudah berlangsung selama lebih dari 1 tahun;

13.Menimbang, bahwa berdasarkan Pasal 210 ayat 1 Kompilasi Hukum Islam bahwa orang yang telah berumur sekurang- kurangnya 21 tahun berakal sehat tanpa adanya paksaan dapat menghibahkan sebanyak-banyaknya $1 / 3$ harta bendanya kepada orang lain atau lembaga di hadapan dua orang saksi untuk dimiliki, dan dalam Pasal 210 ayat 2 Kompilasi Hukum Islam disebutkan bahwa harta benda yang dihibahkan harus merupakan hak milik dari penghibah, sehingga jika ketentuan dalam pasal tersebut dikaitkan dengan fakta di persidangan bahwa hibah yang dilakukan oleh Penggugat terhadap Tergugat telah diketahui dan disetujui oleh anak-anak Penggugat yang lainnya tanpa keberatan sama sekali walaupun objek hibah tersebut diberikan semuanya kepada Tergugat atau melebihi $1 / 3$ harta benda Penggugat dan harta yang dihibahkan oleh Penggugat tersebut adalah harta milik Penggugat. Oleh karena itu, Majelis Hakim berpendapat bahwa hibah yang dilakukan oleh Penggugat kepada Tergugat telah sesuai dengan ketentuan hukum yang berlaku;

14.Menimbang, bahwa meskipun hibah yang dilakukan oleh Penggugat terhadap Tergugat telah sesuai dengan ketentuan hukum yang berlaku, namun hibah Penggugat tersebut dilakukan dengan bersyarat. Oleh karenanya jika didasarkan pada fakta di atas ternyata Tergugat telah melakukan perbuatan melawan hukum (wanprestasi) atau melanggar isi kesepakatan lisan antara Penggugat dan Tergugat, sehingga atas perbuatan Tergugat tersebut Penggugat selaku ayah memohon untuk membatalkan hibah yang telah diberikan kepada Tergugat selaku anak; Menimbang, bahwa berdasarkan Pasal 212 Kompilasi Hukum Islam disebutkan bahwa hibah tidak dapat ditarik kembali, kecuali hibah orang tua kepada anaknya, dan berdasarkan Pasal 1688 KUHPerdata bahwa suatu hibah tidak dapat dicabut dan karena itu pula tidak dapat dibatalkan kecuali; 1. jika syarat-syarat hibah itu tidak dipenuhi oleh penerima hibah, 2. jika orang yang diberi hibah bersalah dengan melakukan atau ikut melakukan suatu usaha pem-bunuhan atau suatu kejahatan lain atas diri penghibah, dan 3. jika penghibah jatuh miskin sedang yang diberi hibah menolak untuk memberi nafkah kepadanya;

15.Menimbang, bahwa dari ketentuan dalam pasal-pasal di atas, menurut pendapat majelis hakim dengan menggunakan tafsir hukum ekstensif bahwa pengertian penghibah jatuh miskin sedang yang diberi hibah menolak untuk memberi nafkah kepadanya bermakna penerima hibah yang menelantarkan atau tidak mem-berikan perhatian kepada pemberi hibah yang telah mengalami suatu keadaan karena alasan force majeur, seperti udzur usia, tidak dapat melakukan hal-hal yang 
bisa dilakukan oleh orang normal pada umumnya dan lain sebagainya sepanjang dimaknai dengan suatu keadaan dimana pemberi hibah tidak dapat lagi memenuhi kebutuhan dirinya sedangkan penerima tidak memiliki kehendak sedikitpun untuk dapat memberikan sesuatu yang bermanfaat bagi pemberi hibah, maka hibah dapat dibatalkan; Menimbang, bahwa dalam ketentuan Pasal 1253 KUHPerdata yang menegaskan bahwa suatu perikatan adalah bersyarat jika digantungkan pada suatu peristiwa yang mungkin terjadi dan memang belum terjadi, baik dengan cara menangguhkan berlakunya perikatan itu sampai terjadinya peristiwa itu, maupun dengan cara membatalkan perikatan itu, tergantung pada terjadi tidaknya peristiwa itu. Oleh karena itu, dengan memperhatikan fakta di persidangan, dimana pemberian hibah dari Penggugat kepada Tergugat selain karena Tergugat tidak memenuhi isi dari perjanjian lisan untuk merawat Penggugat yang sudah tua dan sakit-sakitan, juga karena Tergugat tidak memberikan sesuatu yang bermanfaat bagi Penggugat selaku pemberi hibah sementara kondisi Penggugat sudah tidak dapat memenuhi kebutuhannya atau tidak dapat mengurus dirinya sendiri, maka majelis hakim berkesimpulan bahwa meskipun obyek/barang yang secara de facto dan secara de jure telah dihibahkan kepada Tergugat namun karena syarat itu digantungkan pada suatu peristiwa yang senyatanya tidak dipenuhi oleh Tergugat sebagaimana dalam fakta persidangan, sehingga dengan sendirinya penghibahan itu harus dinyatakan tidak pernah terjadi, ataupun hibah atas obyek sengketa sebagaimana didalilkan oleh Penggugat tersebut patut untuk dibatalkan sebagaimana ketentuan Pasal 212 Kompilasi Hukum Islam dan Pasal 1688 KUHPerdata;

16. Menimbang, bahwa akibat hukum atas batalnya suatu hibah yang diberikan pada penerima hibah yaitu menarik hibah secara sepihak antara kedua belah pihak, sehingga barang yang telah dihibahkan harus dikembalikan, pengembalian mana harus bebas dari segala beban yang telah diletakkan penerima hibah atas barang tersebut, dan untuk selanjutnya penerima hibah wajib menyerahkan kepada si pemberi hibah semua hasil yang diperoleh dari barang yang dihibahkan itu, termasuk benda yang telah dihibahkan sejak penerima hibah lalai memenuhi persyaratan yang ditentukan termasuk di dalamnya adalah segala beban yang telah terletak pada barang hibah itu dan telah melekat padanya harus dibebaskan oleh Tergugat sebelum diserahkan kembali kepada pemberi hibah in casu Penggugat;

17.Menimbang, bahwa oleh karena hibah yang dilakukan oleh Penggugat terhadap Tergugat dibatalkan, maka Akta Hibah Nomor 031/KSO/KBB/I/2014 tertanggal 15 Januari 2014 yang telah diterbitkan atas perjanjian hibah antara Penggugat dan Tergugat patut dinyatakan tidak memiliki kekuatan hukum. Dengan demikian kepada Tergugat atau siapapun yang menguasai objek hibah berupa tanah dan bangunan rumah sebagaimana Sertifikat Hak Milik Nomor 00156 tersebut dihukum untuk mengembalikannya kepada Penggugat dalam keadaan semula dan terbebas dari segala beban apapun;

18.Menimbang, bahwa ternyata Tergugat tidak pernah hadir di persidangan meskipun telah dipanggil dengan sepatutnya, dan gugatan Penggugat dinilai telah beralasan dan berdasar hukum, maka berdasarkan ketentuan Pasal 149 ayat (1) R.Bg, gugatan Penggugat tersebut dikabulkan dengan verstek;

19.Menimbang, bahwa oleh karena gugatan Penggugat dikabulkan, maka sesuai Pasal 192 R.Bg, Tergugat sebagai pihak yang dikalahkan dalam perkara ini harus dihukum membayar biaya yang timbul dalam perkara ini; Mengingat segala ketentuan peraturan perundangan yang berlaku serta hukum syara' yang berkaitan dengan perkara ini.

Menurut Ibu Maryam, Hakim Pengadilan Agama Sungguminasa, dalam wawancara, yang menjadi pertimbangan dalam memutus perkara pembatalan hibah ialah sebagai berikut:

1. Tergugat dalam perkara ini tidak pernah hadir sehingga proses mediasi tidak dapat dilaksanakan, akan tetapi Majelis Hakim tetap berusaha memberikan nasehat kepada Penggugat agar menyelesaikan per-kara ini secara kekeluargaan, namun tidak berhasil;

2. Bahwa yang menjadi penyebab Penggugat mem-batalkan hibah kepada Tergugat adalah karena Tergugat tidak melaksanakan isi perjanjian hibah yang intinya bahwa Tergugat akan menjaga dan memelihara Penggugat dan istrinya sampai meninggal dunia jika Penggugat akan memberikan tanah beserta bangunan rumah sebagaimana gugatan Penggugat, akan tetapi Tergugat justru pergi meninggalkan Penggugat ke Kabupaten Pangkep dan tidak pernah kembali lagi;

3. Tergugat tidak pernah hadir di persidangan meski-pun telah dipanggil dengan resmi dan patut, dan ketidakhadiran Tergugat tersebut tidak ternyata disebab-kan oleh suatu halangan yang sah, maka 
gugatan Penggugat dapat dikabulkan dengan verstek, meskipun gugatan Penggugat dapat dikabulkan dengan verstek, akan tetapi menurut pendapat Majelis Hakim bahwa untuk mengetahui lebih jauh kualitas materiil tentang adanya proses hibah dan alasan pembatalan hibah, maka kepada Penggugat tetap dibebani kewajiban untuk membuktikan dalil-dalil gugatannya.

4. Bahwa terbukti Tergugat telah melakukan perbua-tan melawan hukum (wanprestasi) dengan melanggar isi perjanjian hibah antara Penggugat dengan Tergugat. Berdasarkan uraian di atas dapat diketahui bahwa yang

menjadi pertimbangan hakim dalam memutus perkara hibah ialah karena tidak terpenuhinya syaratsyarat dengan mana penghibahan dilakukan,penerima hibah menelantarkan harta hibah serta telah melakukan perbuatan melawan hukum dengan mana melanggar isi perjanjian hibah.

Sangat jelas bahwa dalam pertimbangan majelis hakim diatas menguraikan alasan-alasan pembatalan dan penarikan kembali suatu hibah berdasarkan Pasal 1688 KUHPerdata dan Pasal 212 Kompilasi Hukum Islam dimana sesungguhnya penarikan suatu hibah adalah haram hukumnya sekalipun pemberian itu dari suami kepada isterinya, namun sebaliknya terbukanya peluang untuk menarik kembali suatu hibah tidak lain dikarena-kan sipenghibah adalah orang tua dari sipenerima hiba sehingga berdasarkan pertimbangan tersebut berdasar-kan kekuasaan hakim guna memutus suatu perkara maka hakim menjatuhkan putusan dengan mengguna-kan ketentuan hukum diluar konteks hukum Islam yakni berdasarka KUHPerdata yang tidak bertentangan dengan syariat Islam. Lain halnya apabila ternyata sipenghibah bukanlah orang tua yang memberikan suatu barang kepada sipenerima hibah lalu kemudian menarik kembali hibahnya maka tentunya ketentuan yang dimaksud dalam Pasal 1688 KUHPerdata tidak berlaku.

\section{KESIMPULAN DAN SARAN}

\subsection{Kesimpulan}

1. Penyebab terjadinya pembatalan hibah ialah apabila barang yang dihibahkan melebihi batas maximum pemberian hibah yaitu $1 / 3$ dari harta kekayaan pemberi hibah, tidak ada ketidaksesuaian dengan maksud ataupun tujuan pemberian hibah serta penerima hibah menolak memberikan nafkah kepada si penghibah ketika jatuh dalam kemiskinan bilamana hibah itu dari orang tua kepada anaknya.

2. Kasus pembatalan hibah No.765/Pdt.G/2015 /PA.Sgm, yang menjadi pertimbangan hakim dalam memutus perkara pembatalan hibah yaitu pemberi hibah menghibahkan hartanya kepada penerima hibah dengan syarat bahwa penerima hibah akan merawat pemberi hibah hingga meninggal dunia tetapi penerima hibah tidak memenuhi syarat tersebut. Dasar hukum pertim-bangan tersebut adalah Pasal 1688 KUHPerdata Ayat (1) serta Kompilasi Hukum Islam Pasal 212 yang dapat dilakukan pembatalan hibah.

\subsection{Saran}

1. Sebelum memberikan suatu hibah perlu diadakan pertimbangan secara matang menyangkut hal-hal yang dapat merugikan pemberi hibah di kemudian hari. Sehingga mempersempit kemungkinan terjadinya pembatalan hibah.

2. Dalam memutus suatu perkara hakim harus mem-berikan pertimbangan hukum yang adil bagi pemberi dan penerima hibah ( tergugat \& penggugat) sesuai dengan nilai-nilai Intrinsik dan dirasakan keadilan bagi masyarakat.

\section{DAFTAR PUSTAKA}

Abdulkadir Muhammad. 2000. Hukum Acara Perdata Indonesia. Cet. Ketujuh, Citra Aditya Bakti : Bandung.

Bahder Johan Nasution, 1997. Hukum Perdata Islam, Mandar Maju: Bandung.

Chairuman Pasaribu, dan Suhrawardi K. Hukum Perjanjian Dalam Islam. Sinar Grafika: Jakarta.

Dadan Mustaqien. 2006. "Dasar-dasar Hukum Acara Perdata”. Insani Cita Press: Yogyakarta.

Eman Suparman, 2011. Hukum Waris Indonesia. PT Refika Aditama: Bandung.

Mertukosumo Soedikno. 1999. Hukum Acara Perdata Indonesia. Yogyakarta Liberty :Yogjakarta.

Mohd. Idris Ramulyo. 1993. Beberapa Masalah Pelaksanaan Hukum Kewarisan Perdata Barat. Sinar Grafika: Jakarta 
Sudarso. 1991. Hukum Waris dan Sistem Bilateral. PT.Rineka Cipta : Jakarta.

Soerjono Soekanto, 2007. Pengantar Penelitian Hukum. UI Press: Jakarta.

Sukarno Aburaera. 2012. Kekuasaaan Kehakiman Indonesia. Arus Timur: Makassar.

Riduan Syahrani, 2009. Buku Materi Dassar Hukum Acara Perdata, Cet. V. PT. Citra Aditya Bakti: Bandung.

R. Subekti, Pokok-pokok Hukum Perdata, Intermasa : Jakarta.

Roihan A, Rasyid. 1991. Hukum Acara Peradilan Agama. Raja Grafindo Persada: Jakarta.

Tamakiran. 2000. Asas-asas Hukum Waris Menurut Tiga Sistem Hukum. PT Pionir Java: Bandung.

Widya Anggraeni, 2006. Tanggung Gugat Pemberi Hibah Akibat Pembatalan Hibah, Universitas Airlangga: Surabaya.

Yahya Harahap. 1986. Segi-segi Hukum Perjanjian. Alumni : Bandung. 